\title{
PENGEMBANGAN HSEGRAF BOARDGAME SEBAGAI MEDIA PEMBELAJARAN KEAHLIAN PRODUKSI GRAFIKA
}

\author{
Besse Irna Tawaddud ${ }^{1 *}$ \\ ${ }^{1}$ Jurusan Teknik Grafika Politeknik Negeri Media Kreatif \\ besse.irnat@polimedia.ac.id
}

\begin{abstract}
ABSTRAK
Abstrak:

Pengabaian standar K3 disebabkan oleh kurangnya tingkat pengetahuan pekerja mengenai pentingnya perlindungan K3. Materi keselamatan dan kesehatan kerja (K3) DI SMK (Sekolah Menengah Kejuruan) menjadi hal yang harus dikuatkan dalam pembelajaran sesuai spesifikasi bidang, misalnya teknik grafika. Selain itu, dunia usaha di berbagai sektor industri akan terbantu jika alumni SMK memiliki pengetahuan K3. Tujuan dari kegiatan pengabdian masyarakat ini adalah untuk untuk memberikan alternatif media pembelajaran aktraktif tentang Kesehatan Keselamatan Kerja (HSE). Metode yang digunakan adalah penyuluhan dan demonstrasi. Hasil yang telah dicapai adalah dari 25 siswa SMK sebagai target audiens yang ikut serta dalam penggunaan media boardgame $92 \%$ (23 siswa SMK) yang menyatakan HSEGRAF Boargame sebagai media interaktif dalam proses edukasi sangat menyenangkan dan $8 \%$ yang menjawab menyenangkan.
\end{abstract}

\section{Kata Kunci: HSEGRAF;Media Pembelajaran;Grafika}

\begin{abstract}
:
The neglect of OHS standards is caused by the lack of knowledge of workers regarding the importance of OHS protection. Occupational safety and health (OHS) material at SMK (Vocational High School) is something that must be strengthened in learning according to field specifications, such as graphic engineering. In addition, the business world in various industrial sectors will be helped if SMK alumni have OHS knowledge. The purpose of this community service activity is to provide an attractive alternative learning media about Occupational Health and Safety (OHS). The method used is counseling and demonstration. The results that have been achieved are that of 25 SMK students as the target audience who participated in the use of boardgame media, 92\% (23 SMK students) stated that HSEGRAF Boardgame as an interactive medium in the educational process was very fun and $8 \%$ answered that it was fun.
\end{abstract}

Keywords: HSEGRA;Learning Media; Graphic

\section{A. LATAR BELAKANG}

Berdasarkan ILO (International Labour Organization), K3 (Kesehatan dan Keselamatan Kerja) merupakan isu global yang menjadi perhatian seluruh negara di dunia (Ismara, 2018). Berbagai aturan yang diterapkan sebagai standar K3 (Kesehatan dan Keselamatan Kerja) dalam sebuah unit kerja sering terabaikan oleh pekerja (Pangkey,2012). Pengabaian prinsip dasar perlindungan K3 (Kesehatan dan Keselamatan Kerja) akan berdampak jangka panjang dan bersifat tidak dapat pulih/irreversible (Kusumadewi, 2015). Pengabaian standar K3 (Kesehatan dan Keselamatan Kerja) yang sering terjadi disebabkan oleh tingkat pengetahuan pekerja mengenai pentingnya perlindungan K3(Kesehatan dan Keselamatan Kerja) yang masih kurang (Yuliandi, 2019). 
Dalam dunia kerja, penerapan K3 (Kesehatan dan Keselamatan Kerja) sangat diperhatikan sehingga materi tersebut penting untuk ada, Dunia usaha akan terbantu sebab tidak perlu mengeluarkan anggaran pelatihan atau pemberian materi terkait keselamatan dan kesehatan kepada para pekerja, terutama lulusan SMK (Sekolah Menengah Kejuruan).

Persepsi akan K3 dipengaruhi oleh pengetahuan. Hal itu sejalan dengan Penelitian Hartono (2018) ditunjukkan dengan nilai rhitung sebesar 0,237 pada taraf signifikansi 5\% (rhitung > rtabel) yaitu 0,237>0,1726 dan (r2) sebesar 0,056 atau 5,6\%. Persepsi penerapan K3 dipengaruhi pengetahuan sebesar 5,6\%(Hartono,2018). Apalagi di SMK, pengetahuan akan K3 masih kurang. Seperti halnya hasil penelitian Monisa (2016) diketahui bahwa penerapan K3 (Kesehatan dan Keselamatan Kerja) terhadap penggunaan alat praktik masuk kategori kurang sebesar $63 \%$, dengan rincian penerapan penggunaan alat dan cara penyimpanan alat (Monisa,2016).

Oleh karena itu, pembelajaran Produksi Percetakan berbasis K3(Kesehatan dan Keselamatan Kerja) membutuhkan alternatif media pembelajaran misalnya melalui game edukasi boardgame. Penggunaan media boardgame sebagai media interaktif dalam proses edukasi menciptakan proses menyerapan informasi yang menyenangkan dan berkualitas Board Game sendiri merupakan media interaktif yang tetap menjadi favorit di kalangan remaja (Tirtouotomo,2015). Hal tersebut terkhusus bagi target audiens usia sekolah dasar hingga sekolah menengah atas, serta mahasiswa. Pernyataan tersebut sejalan dengan Penelitian Iswanto yang menyatakan proses penyerapan informasi mempunyai elemen interaksi dan komunikasi antarpemain selama memainkan boardgame (Istianto, 2013).

Secara umum berbagai macam bidang kegiatan dapat diterapkan dengan konsep game (Kapp, 2012). Dengan adanya kombinasi unsur simulasi, media game akan memberikan hal yang tidak dapat diperoleh di dunia nyata, Game bisa dirancang sedemikian rupa untuk dapat merepresentasikan situasi nyata dan juga menghilangkan beberapa elemen dengan pertimbangan keamanan dan pertimbangan waktu yang dibutuhkan (Rasidi,2016). Games menjadi simulasi dari kondisi nyata (Yusof, 2016)

Dampak kegiatan yang diharapkan sesuai dengan penelitian Karl (2015) yaitu mampu menaikkan level kemampuan responden dalam memahami teori dan penerapan berbagai macam topik yang diajarkan.. Pendapat tersebut sesuai dengan tujuan yang diharapkan dalam pengabdian masyarakat ini. Adapun tujuan dilaksanakannya kegiatan ini adalah untuk memperkenalkan media pembelajaran spesifikasi bidang grafika yang memenuhi aspek K3 (Kesehatan dan Keselamatan Kerja) melalui HSE boardgame

\section{B. METODE PELAKSANAAN}

Metode pelaksanaan pengabdian masyarakat ini adalah penyuluhan dan demonstrasi dengan pendekatan simulasi dalam game. HSE Boardgame ini dirancang untuk bisa dimainkan multiplayer sehingga para pemain dapat memainkan peran sebagai pekerja dalam area produksi percetakan. Secara garis besar gameplay dari permainan ini adalah pemain mengetahui timbal balik pelaksanaan unsur K3 (Kesehatan dan Keselamatan Kerja) yaitu ketaatan dalam menggunakan alat pelindung diri APD (Alat Pelindung Diri) dan kaidah 5R (Rapi, Resik, Rawat, Ringkas, dan Rajin). Adapun mitra dari pengabdian masyarakat ini adalah siswa SMK (Sekolah Menengah Kejuruan) Grafika Lektur berjumlah 25 siswa kelas XI. SMK Grafika Lektur Jakarta merupakan salah satu sekolah swasta yang beralamat di Jalan Kebon Sirih No.46, Kota Jakarta Selatan (Lektur, 2019). 
Kekhasan dari SMK Grafika Desa Putera ini adalah menerapkan pembelajaran spesifikasi Teknik Grafika.

Pengabdian masyarakat ini terdiri dari 7 (tujuh) langkah. Berikut adalah langkahlangkah pengabdian masyarakat yang dilakukan di SMK Grafika Lektur: persiapan materi, perancangan/desain, pembuatan purwarupa, pengujian perseorangan, pengujian kelompok, finalisasi produk,dan implementasi. Langkah-langkah tersebut ada yang dilakukan di rumah (pembuatan HSEGRAF Boardgame) dan di lokasi mitra yaitu di SMK Grafika Lektur.

\section{HASIL DAN PEMBAHASAN}

1. Persiapan materi

Persiapan materi dilakukan dengan menentukan tujuan pembelajaran dan jenis konten. Tahap ini sama dengan tahap analisis dalam model ADDIE (Analyze, Design, Develop, Implement, Evaluate) (Sari,2015) . Hal Ini penting untuk membangun struktur game dan elemen-elemen yang dibutuhkan.

Tabel 1 Deskripsi Label/Kategori Media Pembelajaran HSEGRAF Boardgame

\begin{tabular}{cll}
\hline No. & \multicolumn{1}{c}{ Label/Kategori } & \multicolumn{1}{c}{ Keterangan } \\
\hline 1. & Platform & $\begin{array}{l}\text { Non digital, berupa papan permainan, } \\
\text { bidak, dan dadu }\end{array}$ \\
\hline 2. & Isi Pokok & $\begin{array}{l}\text { Konsep 5R dan penggunaan alat } \\
\text { pelindung diri dalam Produksi Cetak }\end{array}$ \\
\hline 3. & Tujuan Pembelajaran & $\begin{array}{l}\text { Memahami dan menerapkan kosep 5R } \\
\text { dan penggunaan APD dalam bekerja di } \\
\text { unit produksi cetak }\end{array}$ \\
\hline 4. & Kompetensi & $\begin{array}{l}\text { Penerapan budaya K3 yaitu konsep 5R } \\
\text { dan penggunaan APD dalam unit } \\
\text { produksi cetak }\end{array}$ \\
\hline 5. & Target Audiens & $\begin{array}{l}\text { Siswa SMK paket keahlian grafika dan } \\
\text { mahasiswa DIII Teknik Grafika }\end{array}$ \\
\hline 6. & Model Interaksi & Multiplayer Face to Face \\
\hline 7. & Sasaran Aplikasi & $\begin{array}{l}\text { Dunia Pendidikan dan penggunaan } \\
\text { personal }\end{array}$ \\
\hline 8. & Kontro/Interface & $\begin{array}{l}\text { Kotak dadu, papan permainan, dan } \\
\text { bidak }\end{array}$ \\
\hline 9. & Label Game & HSEGRAF Boardgame \\
\hline
\end{tabular}

Berdasarkan Tabel 1 di atas dapat diketahui bahwa Media Pembelajaran HSEGRAF Boardgame merupakan platform non digital yang terdiri dari dadu, papan perminan, dan bidak yang berisi konsep 5R dan penggunaan APD dengan target audiens siswa SMK dan mahasiswa DIII dan paket keahlian grafika

2. Perancangan/Desain

Sebuah program media di dalamnya haruslah berisi materi yang harus dikuasai siswa (Nurseto,2011). Mendesain berdasarkan tujuan dan jenis konten yang akan diajarkan. Perancangan diawali dengan menerjemahkan konsep ilmu yang akan diajarkan dalam sebuah game. Dalam perancangan boardgame edukatif tentang kegiatan di unit produksi grafika ini akan diinformasikan ke dalam 2 bentuk media. 
Media utama dari HSEGRAF boardgame ini akan didukung dengan beberapa media pendukung seperti kemasan dan rulebook

3. Pembuatan purwarupa game

Pembuatan purwarupa dilakukan sebagai persiapan untuk melakukan uji coba terhadap fungsionalitas dari game dan elemen-elemen lainnya.

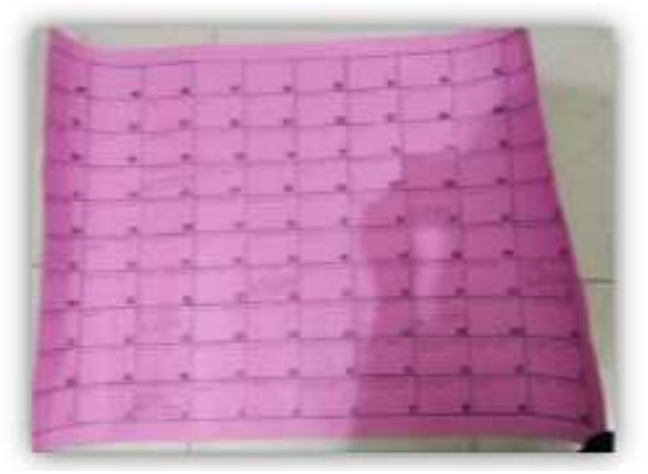

Gambar 1. Purwarupa HSEGRAF Boardgame

Aturan permainan sama seperti permainan ular tangga pada umumnya. Di mana jika bidak jatuh pada kotak yang terdapat tangga akan naik ke kotak selanjutnya sebaliknya jika mendapat ular akan turun ke kotak sebelumnya. Begitu seterusnya hingga diperoleh pemenang yang berhasil sampai di kotak ke-100 lebih dulu

4. Pengujian perseorangan

Pada tahapan ini, purwarupa yang telah dibuat akan diuji untuk mengetahui apakah semua rancangan konsep dan ide telah terintegrasi dan berfungsi dengan baik dalam game. Diperlukan revisi berulang-kali sampai game yang dikembangkan mendekati sempurna menurut sudut pandang perancang.

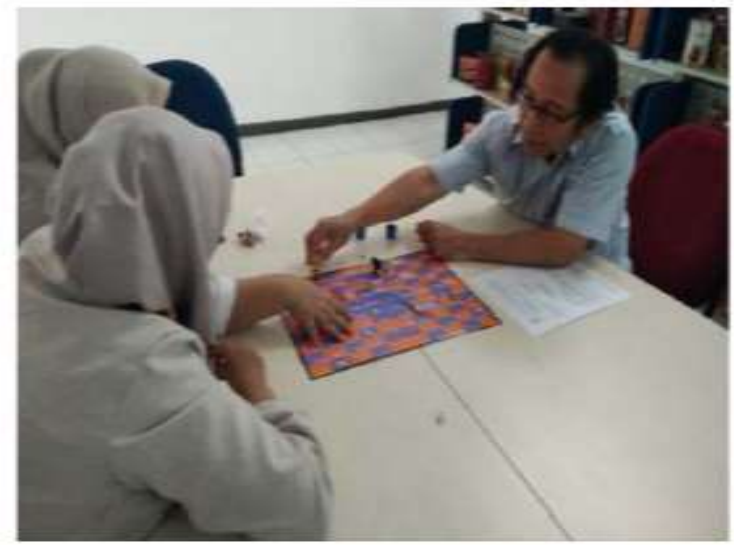

Gambar 2. Pengujian Perseorangan

5. Pengujian pada Kelompok

Uji coba lapangan awal dilakukan dalam skala terbatas ( Tahap ini diperlukan untuk memberikan sudut pandang yang berbeda dari beberapa game tester terhadap game yang dikembangkan. Pengujian kelompok diharapkan akan menjadi wadah memberikan masukan untuk pengembangan game lebih lanjut 


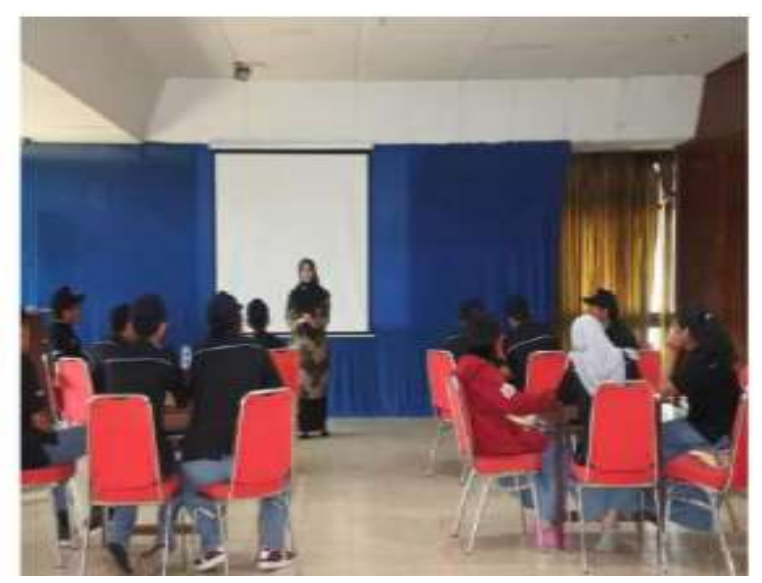

Gambar 3. Pengujian pada Kelompok

6. Finalisasi Produk

Setelah dilakukan revisi berulang sebagai hasil dari timbal balik game tester. Penulis dapat membuat boardgame secara lengkap. Finalisasi produk dipersiapkan untuk implementasi pada subjek penelitian kelas.

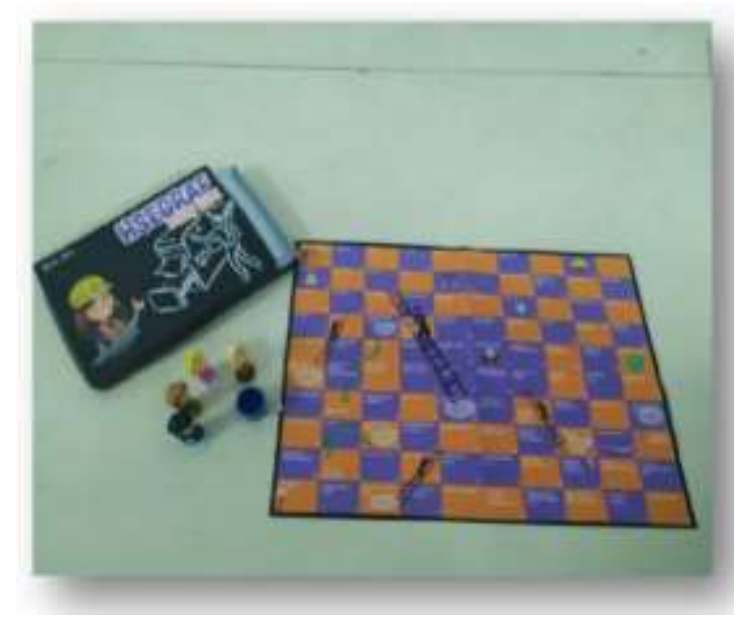

Gambar 4. Finalisasi Produk

Berikut adalah hasil rancangan HSEGRAF boardgame : 1) Papan Permainan Papan permainan boardgame terdiri dari 100 kotak kecil yang isinya 100 kegiatan di unit produksi menggunakan mesin digital dan konvensional percetakan, 2) Beberapa kotak berisi tentang melaksanakan atau tidak melaksanakan penggunaan Alat Pelindung Diri dan Konsep 5R, 3) Bidak Bidak ini digunakan sebagai penanda pemain dalam permainan, dan 4) Dadu merupakan komponen yang paling penting pada permainan ini karena permainan baru bisa dimulai dengan melihat jumlah dadu yang didapatkan.

7. Implementasi

Tahapan implementasi merupakan tahapan terakhir dari serangkaian uji coba. Pada tahapan ini produk yang dihasilkan akan diujicobakan untuk pertama kalinya pada subjek penelitian yang sebenarnya. Sekaligus juga pada tahapan ini akan dilakukan uji kelayakan oleh para ahli. Revisi akhir Semua feedback yang diperoleh dari tahap 
implementasi akan dijadikan bahan pertimbangan untuk melakukan perbaikan terhadap produk yang dikembangkan

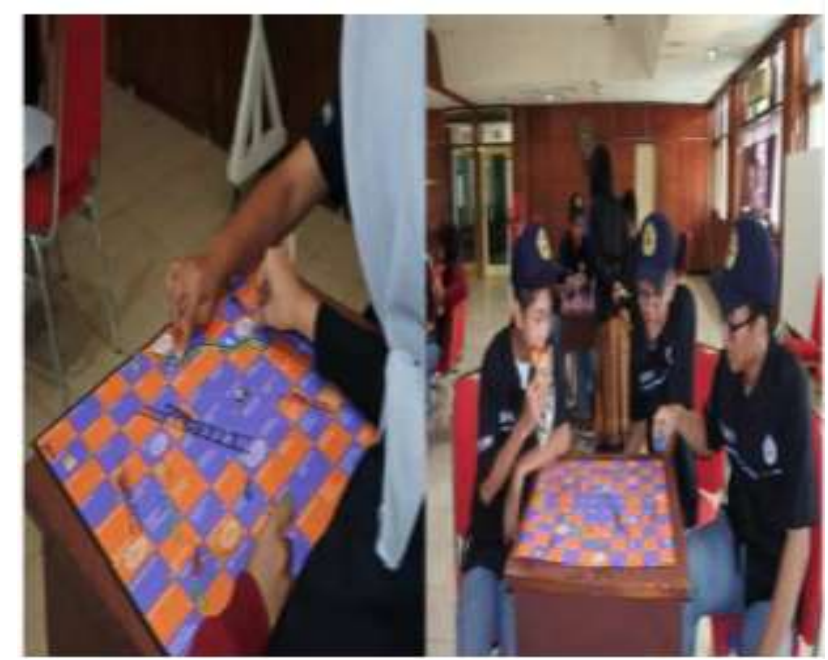

Gambar 5. Implementasi

Kegiatan dimulai dengan melakukan ice breaking terlebih dahulu. Content dari ice breaking tidak jauh dari $\mathrm{K} 3$ dalam bekerja. Ice breaking dilakukan untuk menarik perhatian dan minat mahasiswa siswa SMK Grafika Lektur. Setelah ice breaking dilakukan, dijelaskanlah materi pentingnya penggunaan alat pelindung diri dalam bekerja serta menjelaskan pembiasakan konsep 5R dalam bekerja.

Monitoring dan evaluasi dapat menggunakan Instrumen tes dan kuesioner penghitungan kuantitatif (Gunawan,2016). Adapun hasil kuesioner diperoleh adalah dari 25 siswa SMK sebagai target audiens yang ikut serta dalam penggunaan media boardgame $92 \%$ (23 siswa SMK) yang menyatakan HSEGRAF Boargame sebagai media interaktif dalam proses edukasi sangat menyenangkan dan $8 \%$ yang menjawab menyenangkan.

Kendala yang dihadapi saat pengadian masyarakat ini adalah pengumpulan audience (siswa) dalam aula memakan waktu karena siswa random dari beberapa kelas sehingga pelaksanaan pengabdian bergeser beberapa menit.

\section{SIMPULAN DAN SARAN}

Simpulan dari pengabdian masyarakat ini adalah telah terlaksananya dengan baik pengenalan media pembelajaran spesifikasi bidang grafika yang memenuhi aspek $\mathrm{k} 3$ melalui HSE boardgame. Total 25 siswa SMK sebagai target audiens yang ikut serta dalam penggunaan media boardgame $92 \%$ (23 siswa SMK) yang menyatakan HSEGRAF Boargame sebagai media interaktif dalam proses edukasi sangat menyenangkan dan $8 \%$ yang menjawab menyenangkan

Saran dari pelaksanaan pengabdian masyarakat ini adalah diharapkan permainan boardgame ini dapat dikembangkan lagi dalam bentuk digital dan dijadikan sebagai salah satu media pembelajaran khususnya di SMK dan DIII Jurusan Teknik Grafika. 


\section{UCAPAN TERIMA KASIH}

Penulis mengucapkan terima kasih kepada P3M Politeknik Negeri Media Kreatif atas perizinan, Yayasan Lektur Grafika yang telah bersedia menjadi mitra dan sambutannya yang hangat, serta pihak-pihak yang tidak bisa disebutkan satu persatu yang telah memberikan kontribusi selama pembuatan HSEGRAF Boardgame.

\section{DAFTAR RUJUKAN}

Gunawan et al. (2016). Impelementasi Monitoring dan Evaluasi Proses Lesson Study di FKIP UM Surabaya. Jurnal Didaktis, Vol. 15, No. 1, Hal 1 - 116, Oktober 2015, ISSN 1412-5889.

Hartono, Arif dan Sutopo. (2018). Pengaruh Pengetahuan, Sikap, dan Lingkungan Kerja terhadap Persepsi Penerapan Keselamatan dan Kesehatan Kerja. Jurnal Dinamika Vokasional Teknik Mesin ISSN 2548-7590 (media online) Volume 3 Nomor 2 Hal 76-81 ISSN 2598-392X (media cetak)

Ismara, Ketut Ima.(2018).Prinsip-Prinsip Keselamatan dan Kesehatan Kerja dalam Lomba Kompetensi Siswa SMK.Jogjakarta : UNY Press.

Istianto, T., Tanudjaja, B. (2013). Perancangan Board Game tentang Bercocok Tanam di Rumah. Universitas Kristen Petra Kementerian Pendidikan dan Kebudayaan Direktorat Jenderal Guru dan Tenaga Pendidikan. 2018. Modul Pengembangan Keprofesian Berkelanjutan SMK

Kusumadewi, Chika.(2015). Penerapan Safety Game untuk Meningkatkan Pengetahuan K3 Level Pekerja dalam Kegiatan Penebangan di KPH Madiun. Skripsi. Fakultas Kehutanan. Institut Pertanian Bogor.

Lektur Grafika Media, Yayasan. (2019). SMK Yayasan Lektur Grafika Media. Diakses dari www.smkgrafikalektur.sch.id

Monisa. (2016).Penerapan Kesehatan dan Keselamatan Kerja (K3) Siswa di Workshop Tata Kecantikan Rambut SMK Negeri 7 Padang.Skripsi Universitas Padang.

Nurseto, Tejo.(2011).Membuat Media Pembelajaran yang Menarik . Jurnal Ekonomi \& Pendidikan, Volume 8 Nomor 1, April 2011

Pangkey, Febyana dan Grace.(2012) Penerapan Sistem Manajemen Keselamatan dan Kesehatan Kerja (SMK3) pada Proyek Konstruksi di Indonesia 100 (Studi Kasus: Pembangunan Jembatan Dr. Ir. Soekarno-Manado). Jurnal Ilmiah media Engineering Vol. 2, No. 2, Juli 2012 ISSN 2087-9334, 100-113

Rasidi, Nanang et al. (2016). Perancangan Accounting Boardgame (ABG) untuk Belajar Siklus Akuntansi. National Conference On Economic Education ISBN: 978-60217225-5-81036

S.A, Sari dan Sri. (2015). The Development of Preparedness Board Game as A Learning Media for Natural Disaster. Proceedings of The 5th Annual International Conference Syiah Kuala University (AIC Unsyiah) 2015 In conjunction with The 8th International Conference of Chemical Engineering on Science and Applications (ChESA)

Sekarningrum, Andini, et al.(2014).Pengembangan dan Implementasi Model Pembelajaran Predict, Planning, Observe, Explain, Write (P2OEW) pada Materi Pencemaran Kelas X SMA Negeri 7 Surakarta. Jurnal Inkuiri. ISSN: 2252-7893, Vol 3, No. III, 2014 (hal 1-10)

Tirtoutomo, Stanley.(2015). Perancangan Media Board Game untuk Remaja Tentang Perilaku Baik dan Buruk Jurnal Desain Komunikasi Visual, Fakultas Seni dan Desain, Universitas Kristen Petra 
28 | PEKAMAS (Pengabdian Kepada Masyarakat) | Vol. 1, No. 1, Juli 2021, hal. 21-28

Yuliandi, Cindy dan Eeng.(2019). Penerapan Keselamatan dan Kesehatan Kerja (K3) di Lingkungan Kerja Balai Inseminasi Buatan (BIB) Lembang. Jurnal Manajerial, Vol. 18 No. 2, 98 http://ejournal.upi.edu/index.php/manajerial/

Yusof, Sharul. (2016). A Study on the Effectiveness of a Board Game as a Training Tool for Project Management. Journal of Telecommunication, Electronic and Computer Engineering ISSN: 2180-1843 e-ISSN: 2289-8131 Vol. 8 No. 8 